\title{
Pastoralism in Kalmykia: Historical Experience and Modernity
}

\author{
Komandzhayev A.N. \\ Kalmyk State University named \\ after B. B. Gorodnikov \\ Elista, Russia \\ ak.narma@mail.ru \\ Abeyeva O.N. \\ Kalmyk State University named \\ after B. B. Gorodnikov \\ Elista, Russia \\ kalmhistory@yandex.ru
}

\author{
Komandzhayev E.A. \\ Kalmyk State University named \\ after B. B. Gorodnikov \\ Elista, Russia \\ kalmhistory@yandex.ru \\ Tsekeyeva T.E. \\ Kalmyk State University named \\ after B. B. Gorodnikov \\ Elista, Russia \\ kalmhistory@yandex.ru
}

\begin{abstract}
The article discusses the developing of pastoralism in Kalmykia that is being studied in a limited number of works. Moreover, the researchers did not try to make comparative historical parallels with modernity. Even though nomadology has been developing over two centuries, in the modern period, discussions are still ongoing on its key problems. It is largely due to the complex and protracted transition in Russian historiography from the formational to civilizational approaches. In this regard, the authors of this article are trying to consider the historical experience of the Kalmyk nomadic economy and to determine its criteria indicators and development trends. As an example, the authors have studied the beginning of the 20th century, because it was at this time that the optimal basic elements in the development of pastoralism were formed in Kalmykia. It was a period of intensive involvement of the region in the all-Russian market that caused significant changes in Kalmyk economy: an active transition to settled life, the beginning of the multi-sector economy formation, the development of economic zoning, changes in the specific structure of Kalmyk farming under the influence of market conditions. The main indicators of the Kalmyk economic culture, the role and place of the Russians of the Co-Ukrainian resettlement population in the agrarian evolution were allocated. According to the authors, in the region at the beginning of the 20th century, there was a rational relationship between man and nature, which led to a relative ecological balance. The authors paid attention to the current state of the agrarian production in Kalmykia, identified its positive and negative sides, and offered their own vision of the prospects for pastoralism, considering the centuries-old historical experience of the Kalmyks
\end{abstract}

Keywords - nomads, kalmyks, pastoralism, farming, economic culture, modernity

\section{INTRODUCTION}

The topic is relevant due to several reasons. First, the study of Kalmyks' economic activities is necessary in the course of the modern search for the lost criteria of national identity, among which the people's economic traditions are basic. Secondly, considering historical experience is important in the matter of harmonizing interethnic relations in a polyethnic region. Thirdly, the problem is a little-studied one. If one or another aspect of Kalmyk farming development (number, structure, dynamics of development) is studied partly well. However, not enough researchers pay attention to the interrelation of historical experience with modern phenomena. The last situation was the subject of discussion only in a small number of journalistic articles.

\section{PROBLEM STATEMENT}

The Kalmyks nomadic economy was studying in the XIX century by I.V. Bentkovskiy, I. Zhitetskiy, V.N. Bakunin, N.Ya. Bichurin, N. Nefed'yev, P.I. Nebol'sin. Some of these works were studies and notes by contemporaries, others were based on the study of written sources, and third were collections of statistical materials. Already in the works of I. Bentkovskiy and I. Zhitetskiy, the relationship of the nomadic lifestyle of Kalmyks with natural and climatic conditions were presented. They considered this type of Kalmyk economic management to be justified and correct in the arid steppe zone (Bentkovskiy, 1868; Zhitetskiy, 1893). In the Soviet period. the detailed comprehensive description of the Kalmyk animal and animal management is presented by the works of historians N.N. Palmov, U.E. Erdniev. (Palmov, 1926-1932; Erdniev, 1985) and others. In modern literature, the works of A.N. Komandzhayev and L.Ts. Badmakhalgayev (Komandzhayev, 1999; Badmakhalgayev, 2003) should be mentioned. These studies draw attention to the importance of 
historical traditions in the economy of modern Kalmykia. For the sake of justice, it is necessary to point out the presence of a number of works on pastoralism production in other nations and, above all, in the Mongols, who are similar in culture and life style to Kalmyks (Grayvoronskiy, 1997).Maintaining the Integrity of the Specifications.

\section{RESEARCH QUESTIONS}

Despite the long period of studying the Kalmyks farming industry, many of the issues are not fully analyzed. Even in such a simple matter as the determination of the livestock number of the Kalmyk in the early 20th century, researchers give incomplete figures. This incompleteness is explained by the fact that historians did not consider the livestock population in the Russian-Ukrainian migrant economy and the livestock number on leased pastures. To this the difficulty of collecting statistical material from the nomadic population is added. Also, Kalmyks tried to present understated numbers in order to avoid high tax levies. Therefore, the authors of this article are faced with the task of determining the exact number of livestock animals in Kalmykia at the beginning of the 20th century. It should be borne in mind that the optimal period for comparison with the present day, in our opinion, is precisely the beginning of the 20th century. During this period, the most favorable economic situation developed here: the size and composition of the population, the general economic structure, the specific distribution of living conditions, the determined market conditions, trade relations, labor market, ways of communication, etc.

In the Soviet period, the overall economic structure had undergone significant changes. The share of crop production had unreasonably increased, traditional livestock breeding had disappeared (camel breeding, horse breeding, sheep breeding of Kalmyk breed). The transition to sedentary livestock breeding without regard to the forage base took place. It caused the degradation of pastures and intensive desertification of land. In this regard, some of the lost elements of the traditional economic culture of Kalmyks, which can be considered in the economy of modern Kalmykia, should be identified. The authors believe that it is necessary to pay attention to the influence of the all-Russian market on Kalmyk farming, the definition of market-oriented livestock sectors, the folding of pricing policies, regional distinctiveness in the development of Kalmyk farming. The authors draw attention to the insufficiently studied problem of water supply in the region and the procurement of feed for livestock.

\section{PURPOSE OF THE STUDY}

The purpose of the study is to determine the possibility of the historical experience of Kalmyks pastoralism at the present stage

\section{RESEARCH METHODS}

Various research methods were used. A system analysis provides to consider the development of Kalmyks farming at the beginning of the 20th century as a part of the traditional culture, changing under the socio-economic development of the country in that period. A principle of historicism provides a picture of the real perception of the past in dynamics and statics. Objectivity is based on the involvement of statistical and written sources, including first introduced into scientific circulation. At the same time, when analysing the Kalmyk economy dynamics, statistical materials were grouped not by annual indicators, but by five years. This technique, in our opinion, contributes to a more objective characterization of the unstable nomadic and semi-nomadic farms in the steppe arid zone. In the analysis the pre-revolutionary and modern economy of Kalmykia broad comparative historical parallels were madeSome Common Mistakes.

\section{FINDINGS}

Economic traditions are the basic element of the culture. Changes in this area and, moreover, the destruction of these traditions can lead to global changes in the way of life and affect the decline of all aspects of the material and spiritual ethnic group culture. A similar negative is observed in varying degrees among many peoples of our country, including the Kalmyks, whose economic experience is not sufficiently considered in the modern farming infrastructure. At times, the idea of the connection of historical experience and modernity is completely ignored in view of the irreversible transition of Kalmyks to a settled way of life in the 20th century. Meanwhile, the study of sources and literature on the nomadic economy of Kalmyks shows that using the experience of ancestors can contribute to the revival and development of Kalmyk culture, and have a positive economic and environmental effect.

The eight Kalmyk uluses of the Astrakhan province were consolidated into a single administrative-territorial unit called the Kalmyk Steppe. After the administrative reform of 1910, there were 108 hotons and 34 aimaks in the Kalmyk steppe (Materials, 1910). In addition, there was the Bol'shederbetovskiy ulus, numbering 12 aimaks, as part of the Stavropol province. These 9 Kalmyk uluses occupied at the beginning of the 20th century an area of 7.9 million tithes, of which 6.7 million tithes belonged to Kalmyk proper societies, the leased land amounted to 800 thousand tithes, the cattle driving paths to the Volga - about 100 thousand tithes, 10 miles along the right bank of the Volga, used by Kalmyk, Russian-Ukrainian Cossack too - about 300 thousand tithes (Populated place, 1905; Results of land Management, 1912).

According to the First General Census of 1897, the Kalmyk population of Astrakhan and Stavropol gubernias was 140.3 thousand people (Pervaya, 1899; Pervaya, 1905). It should be said that these figures represent an underestimate population, since the census at a time could not cover the entire nomadic population. According to the updated data of the annual reports of the Administration of the Kalmyk People of the Astrakhan Province and the Chief Representative of the Nomadic Peoples of the Stavropol Province, the Kalmyk population in these ulus was more than 150 thousand people (Komandzhayev, 1999).

The question of the water supply of the region has always been important for Kalmykia. According to the survey of 1909 in the Kalmyk steppe there were reservoirs (lakes and ponds) with an area of 45.6 thousand tithes (Materialy, 1910). In fact, 
this figure was 2 times overestimated, since it included the low-lying parts of the Volga delta (more than 23 thousand tithes) that were poured in the spring. Open ponds were used for watering animals. In Kalmykia, supplies of fresh drinking water were extremely limited. Drinking water wells were located within the Ergeninskaya hill chain. According to the annual reports of the management of the Kalmyk people at the beginning of the 20th century, there were more than 5,000 wells in the Kalmyk steppe.

The next question is the livestock number in Kalmykia in the period. This issue is particularly relevant today in connection with the current economic and environmental situation in the region. So, it is closely connected with the load on pastures. According to the specified information, during the Soviet years the sheep number doubled, and the number of cattle, on the contrary, decreased by $18 \%$. It should be considered that today the number of horses has significantly decreased (20 thousand heads), and the number of camels does not even reach 1000 heads. Summarizing the calculations and converting the livestock of animals into conventional units of livestock ( 4 small heads per large unit), the authors determined that the increase in livestock production in Kalmykia during the Soviet period was only $30 \%$.

The question of the livestock distribution is important. This factor must be considered when analyzing the economic zoning of the territory of modern Kalmykia. According to archival data, the largest livestock holders were residents of two northern uluses, who had more than $45 \%$ of the total livestock in the Kalmyk steppe. The analysis of the livestock area specificity will be fairly objective, if the livestock number per one farm is determined. As a result of the calculations, it turned out that the most cattle farms are the farms of the central part of Kalmykia, where the land per farm amounts to 20-28 conventional units of cattle.

Thus, livestock breeding was not the only source of income for Kalmyk families that provided the necessary living wage. Farming and fishing, salt-making, hiring for agricultural work were added to fsrming. Therefore, the real norms of livestock breeding, dictated by life itself, were formed. They totaled almost 17 conventional units of large livestock per household, and not 29.3 (data from pre-October statistics).

The materials on the regional specialization of the livestock industry in Kalmykia indicate the following. Breeding cattle prevailed over other livestock industries in the north, where the share of cattle accounted for more than $50 \%$ of the total livestock. Here we are forced to agree with those researchers who argued that cattle are less adapted to nomadism. According to the observations of I. Zhitetskiy, this led to a decrease in the rate of farms movement almost twice: from 400 to 200 versts per year (Zhitetskiy, 1893). In the east of the Kalmyk steppe, the "nomadic" branches prevailed: husbandry and horse breeding.

The expected picture was observed in the Bol'shederbetovskiy ulus of the Stavropol province. Almost $60 \%$ here was the share of cattle, $32 \%$ - sheep in terms of conventional unit, $8 \%$ - horses. The transition to settled economic management has taken place completely.

In this regard, the authors turn to the modern distribution of industries in Kalmykia. According to statistics, the number of cattle in private and public herds was 361.6 thousand heads, sheep - 3282.3 thousand heads, pigs - 79.3 thousand heads. The number of horses (20 thousand) and camels is so small that there is almost no need to mention them in official reports. What about traditional farming industry, at the end of the 20th century, the share of cattle in the total number of farm animals was $30.5 \%$, and sheep - 69.5\%. Thus, it can be concluded that there was the need for a radical change in the ratio of livestock numbers in the agricultural sector, since the Kalmyks, who had completely reverted to settlement, unexpectedly increased the share of sheep farming by almost 2 times. And this, in turn, requires considerable pasture space as well. Moreover, this was due to a sharp reduction in the proportion of cattle (from $44 \%$ to $30.5 \%$ ), which is most suited for stables.

Horse breeding and camel breeding have become victims of unequal competition and are reduced to the present time almost to zero. Under the condition of full uptake of sheep and horse breeding by sheep, the number of small ruminants should not exceed $55 \%$ of the total livestock of farm animals.

In connection with the need to turn to the historical experience, the answer to the question about the load on pastures in Kalmykia in the early twentieth century is important.

According the calculations, the load on pastures was less than 0.15 standard units of cattle per tithe. That is, 6.8 acres was allocated for one conventional unit of cattle. The authors include the maximum number of livestock (including "foreign" livestock) in the calculation. The comments of our ancestors and specialists of that period testify that such a load was the maximum permissible and sometimes destructive for the eastern part of the territory of Kalmykia. Therefore, the Kalmyks regularly opposed the irrational overloads of pastures that were observed at that time, especially in the resettlement areas: 0.9 conventional units of livestock per tithe, which was almost 6 times higher than the above allowed livestock. This suggests that the process of perceiving the culture of animal husbandry among the Kalmyks by the settlers was just beginning. Naturally, this overloading of pastures in Russian Ukrainian villages forced migrants to hire pastures from neighboring Kalmyk communities. At the end of the 20th century, according to our approximate calculations, the load on pastures was $0.42-0.45$ conventional units of large livestock per hectare. It was one of the main reasons for the acceleration of the desertification processes of the Kalmyk steppes.

The data on the profitability of livestock industries in Kalmykia, which is very relevant today in market conditions, is very indicative.

According to the yield of small cattle, the sheep-breeding Aleksandrovskiy ulus naturally takes the leading position. The low yield from small cattle in Erketenevskiy ulus, which has traditionally been sheep-breeding, is unexpected. First, other 
types of animals here gave low incomes compared to other ulus. Secondly, there was probably less pronounced marketability of livestock with the ensuing consequences: the dominance of extensive methods, poor communication with the market and, of course, low returns to livestock.

The profitability of camel breeding was significantly lower compared to other cattle species. It seems surprising that the smallest camel population in Maloderbetovskiy ulus was a leader in terms of profitability from this type of livestock industry.

The analysis of trade dynamics of 1892-1917 allows to state the fact that the supply of horses and cattle steadily increased by $20-30 \%$; and the sales of camels and sheep also decreased. The only exception may be the years of the First World War, which sharply disrupted the existing commodity balance. Only in the first year of the war in the Kalmyk steppe, according to the reports of the Office of the Kalmyk people, the following were implemented: camels 1969 heads $(7.7 \%)$; horses - 10158 heads (13.1\%); large cattle - 55905 heads $(28.9 \%)$; sheep - 167,198 heads $(20.6 \%)$; goats - 1979 heads (11\% of their total number). They accounted for almost $20 \%$ of the total livestock of all animal species in terms of conventional units of cattle. Thus, a significant increase of the market supply amounted to $7.2 \%$ (compared to 1912). It disrupted the harmonious development of the livestock industry in Kalmykia.

However, $12.3 \%$ is only the share of livestock sold. In addition, according to selective data based on materials from a survey of 1909 , it follows that $5.2 \%$ of the livestock population of the Kalmyk steppe used to meet nutritional needs and $0.3-0.5 \%$ sacrificed churches. If the annual loss of livestock $(6 \%)$ is added to this, then the total share of the "waste" of livestock farming was about $24 \%$. It is the allowable consumption threshold derived by our ancestors that allowed the livestock industry of Kalmykia not only to selfregenerate, but also to ensure growth

The authors did not mention many of the characteristic features of animal husbandry culture in Kalmyks (forms, ways of wandering, etc.), the use of which is currently difficult. The analysis of the same problems gives a conclusion: the experience of the past can also be expressed in specific economic categories.

The preferred spelling of the word "acknowledgment" in America is without an "e" after the "g." Avoid the stilted expression "one of us (R. B. G.) thanks ...". Instead, try "R. B. G. thanks...". Put sponsor acknowledgments in the unnumbered footnote on the first page.

\section{CONCLUSION}

The analysis of the material on the state of Kalmyk pastoralism of the beginning of the 20th century showed its economic efficiency and environmental value. In the period under study, the optimal economic structure was established in the Kalmyk uluses: a fully justified ratio of various sectors (animal husbandry, agriculture, fishing) and their zoning, a favorable demographic situation, a rational land use. The integration of Kalmykia into the all-Russian market space has made its own adjustments to the specific ratio of animals: the share of cattle breeding has increased, the scale of sheep breeding, especially fine-fleeced, has increased, the number of horses and camels has decreased. This was evidence in the beginning of the transition of Kalmyks to a sedentary lifestyle, as evidenced by information about the presence of stationary buildings and forage for Kalmyk livestock producers. In the south-west of Kalmykia, the population has completely passed over to residency and agricultural production. Thus, at the beginning of the 20th century, the basic elements of the Kalmyk livestock culture including the determined load on pastures, the rational use of grasslands and water sources were formed.

\section{Acknowledgments}

The article was prepared in the framework of the research project of the internal university grant of Kalmyk State University on the theme "Economic traditions of Kalmyks: historical experience and modernity".

\section{References}

[1] O.A. Aver'yanov, "Kratkiy otchet rabot po ukrepleniyu peskov Kalmytskoy stepi za period s 1908 po 1910 god", A brief report of the work on strengthening sands in the Kalmyk steppe from 1908 to 1910 , Astrakhan, 1912.

[2] L.Ts. Badmakhalgayev, "KHozyaystvo Kalmykii: evolyutsiya potentsial ustoychivogo razvitiya", [Kalmyk economy: evolution and potential for sustainable development], Elista: Dzhangar, 2003

[3] I.V. Bentkovskiy, "Do the waters and steppes of the Bol'shederbetovskiy ulus meet the conditions of the colonization of the Kalmyks?", Sbornik statisticheskikh svedeniy o Stavropol'skoy gubernii:1, Collection of statistical information about the Stavropol province: 1, Stavropol', 1868.

[4] A.D. Gombozhapov, "On the issue of the problem of nomadism in modern Mongolia", Vlast' -Power. 9, 2009, pp. 129-132.

[5] V.V. Grayvoronskiy, "Sovremennoye aratstvo Monogolii: sotsial'nyye problemy perekhodnogo perioda (1980-1995)", Modern aratism of Mongolia: social problems of the transition period (1980-1995), Moscow: Vostochnaya literatura, 1997.

[6] V.V. Grayvoronskiy, "Mongolia: grazing and nomadic livestock raising is a record increase in livestock and an environmental threat", Aziya Afrika segodnya - Asia and Africa today, 9, 2018, pp. 49-55.

[7] I.A. Zhitetskiy, "Ocherki byta astrakhanskikh kalmykov", Etnograficheskiye nablyudeniya 1884-1886 gg. [Essays on the life of the Astrakhan Kalmyks. Ethnographic observations 1884-1886]. Moscow: Eipografiya Volchaninova M.G, 1893.

[8] "Itogi zemleustroystva. Graficheskoye izobrazheniye deyatel'nost Zemleustroitel'nykh Komissiy za pervoye pyatiletiye”, Results of land management, Graphic representation of the activities of the Land Management Commissions for the first five years, Saint-Petersburg: Tipografiya T-va R.Golike i A. Vil'borg, 1912

[9] A.N. Komandzhayev, "Khozyaystvo i sotsial'nyye otnosheniya v Kalmykii v kontse XIX-nachale XX veka", Economy and social relations in Kalmykia in the late 19th and early 20th centuries, Elista: Dzhangar,1999.

[10] "Materialy statistiko-ekonomicheskogo i estestvenno-istoricheskogo obsledovaniya Kalmytskoy stepi Astrakhanskoy gub", Materials of statistical-economic and natural-historical survey of the Kalmyk steppe of the Astrakhan Province, In 2 Parts. Astrakhan: Parovaya Gubernskaya tipografiya, 1910

[11] Naselennyye mesta Rossiyskoy imperii v 500 i boleye zhiteley s ukazaniyem vsego nalichnogo $\mathrm{v}$ nikh naseleniya $\mathrm{i}$ chisla zhiteley preobladayushchikh veroispovedaniy po dannym Pervoy vseobshchey 
perepisi naseleniya 1897 goda, 1905, Saint-Petersburg: Tipografiya Obshchestvennaya pol'za.

[12] N.N. Pal'mov, "Etyudy po istorii privolzhskikh kalmykov", V 5-ti chastyakh, Studies on the history of the Volga Kalmyks, In 5 parts, Astrakhan: Izd. Kalmytskogo Oblastnogo ispolnitel'nogo komiteta, 1926-1932.

[13] “Pervaya vseobshchaya perepis' naseleniya Rossiyskoy imperii 1897 g, II", Astrakhanskaya guberniya, [The first general census of the population of the Russian Empire in 1897, II. Astrakhan province], Saint-Petersburg: Izdaniye TSentral'nogo stat.komiteta Min-va vnutr.del, 1899.

[14] “Pervaya vseobshchaya perepis' naseleniya Rossiyskoy imperii $1897 \mathrm{~g}$ KHVII", Stavropol'skaya guberniya, [The first general census of the population of the Russian Empire in 1897 XVII. Stavropol Province], Saint-Petersburg: Izdaniye TSentral'nogo stat.komiteta Min-va vnutr.del, 1905.

[15] U.E. Erdniyev, "Kalmyki. Istoriko-etnograficheskiye ocherki", 3 izd. [Kalmyks. Historical and ethnographic essays. 3rd ed.]. Elista: Kalm. kn.izd-vo, 1985.

[16] G.S. Yaskina, "The enclaves of a nomadic civilization in individual countries: the experience of Mongolia", The nomadic civilization of the Great Steppe: the current context and historical perspective, [Materialy Mezhdunarodnoy nauchnoy konferentsii i Mezhdunarodnogo nauchnogo foruma - Materials of the International Scientific Conference and the International Scientific Forum. Elista: Dzhangar], pp.43-51, 2008. 